\title{
MicroRNA-33b inhibits lung adenocarcinoma cell growth, invasion, and epithelial-mesenchymal transition by suppressing Wnt// -catenin/ZEB1 signaling
}

\author{
JINGJING QU，MIN LI，JIAN AN，BINGRONG ZHAO，WEN ZHONG, \\ QIHUA GU, LIMING CAO, HUAPING YANG and CHENGPING HU
}

Department of Respiratory Medicine, Xiangya Hospital, The Central South University, Changsha, Hunan 410008, P.R. China

Received August 21, 2015; Accepted September 14, 2015

DOI: $10.3892 /$ ijo.2015.3187

\begin{abstract}
Altered expression of microRNA (miRNA) is associated with lung carcinogenesis and metastasis. Our previous study of lung cancer miRNAs using the gene chip assay demonstrated altered miR-33b expression in lung adenocarcinoma. The present study further investigated miR-33b expression, function, and gene regulation in lung cancer cells in vitro and in nude mouse xenografts. Our data showed that the level of miR-33b expression was dramatically decreased in lung adenocarcinoma cell lines and tissues and that the reduced miR-33b expression was associated with tumor lymph node metastasis. Furthermore, restoration of miR-33b expression inhibited lung adenocarcinoma cell proliferation, migration, and invasion and tumor cell epithelial-mesenchymal transition (EMT) in vitro. Luciferase assay revealed that miR-33b bound to ZEB1 3'-UTR region and inhibited ZEB1 expression, while expression of ZEB1 mRNA and miR-33b was inversely associated with lung adenocarcinoma cell lines and tissues. Subsequently, we found that miR-33b suppressed the activity of WNT/ $\beta$-catenin signaling in lung adenocarcinoma cells and in turn suppressed tumor cell growth and EMT in vitro and in vivo nude mouse xenografts. In conclusion, the present study provided novel insight into the molecular mechanism of lung adenocarcinoma progression. MicroRNA-33b should be further investigated as a potential therapeutic target in human lung adenocarcinoma.
\end{abstract}

Correspondence to: Professor Chengping $\mathrm{Hu}$, Department of Respiratory Medicine, Xiangya Hospital, The Central South University, Changsha, Hunan 410008, P.R. China

E-mail: huchengp28@126.com

Abbreviations: NSCLC, non-small cell lung cancer; EMT, epithelial-mesenchymal transition; LA, lung adenocarcinoma; 3'-UTR, 3'-untranslated region

Key words: microRNA, miR-33b, epithelial-mesenchymal transition, lung adenocarcinoma, invasion and migration

\section{Introduction}

Lung cancer is one of the most significant health challenges worldwide. Non-small cell lung cancer (NSCLC) consists of $\sim 80 \%$ of lung cancer cases and is further categorized into lung adenocarcinoma, squamous cell carcinoma and large cell carcinoma (1). A previous study demonstrated that these subtypes may be associated with different NSCLC etiology. For example, lung squamous cell carcinoma and large cell carcinoma are significantly linked to tobacco smoke, whereas lung adenocarcinoma occurs more frequently in women or individuals who never smoke tobacco $(2,3)$. Lung adenocarcinoma accounts for $\sim 40 \%$ of all lung cancers and frequently occurs in the lung periphery (1). Overall, NSCLC is frequently diagnosed at advanced stages of the disease and overall 5-year survival rate of patients with lung adenocarcinoma is still up to $15 \%(4,5)$. Lung cancer metastasis is associated with poor clinical outcome. Previous studies demonstrated that metastasis is involved in several critical steps to establish tumor lesions in other organs. Tumor cells break through the basement membrane and invade into nearby blood vessels or the lymphatic system. They spread into distant organs or tissues via the circulatory system, and settle down in the new location and grow into a secondary tumor lesion in the metastatic sites (4). To date, tumor metastasis is responsible for $\sim 90 \%$ of all cancer-related deaths. Thus, further study of cancer metastasis (cause, mechanism or clinical control) could lead to reduction of cancer-related deaths and also improve quality of life in patients.

Indeed, recent evidence suggests that tumor cell epithelial-mesenchymal transition (EMT) promotes tumor cell migration, invasion and metastasis (6-9). EMT is a process in which epithelial tumor cell loses its polarity and converts into a mesenchymal phenotype. The control or inhibition of tumor cell EMT could effectively block metastasis or growth of NSCLC (6-9). During EMT, expression of epithelial markers, such as E-cadherin, are downregulated, whereas expression of the mesenchymal cell markers (vimentin or smooth muscle actin) is upregulated. EMT enables tumor cell migration, and invasion and metastasis (10). More recently, Zinc finger E-boxbinding homeobox 1 (ZEB1) protein was shown to be the key transcriptional factor in the regulation of NSCLC cell EMT 
Table I. RNA oligo sequences.

\begin{tabular}{lc}
\hline Oligo & \multicolumn{1}{c}{ Oligo sequences } \\
\hline ZEB1-siRNA & S: 5'-GGAUCAACCACCAAUGGUUTT-3' \\
& A:5'-AACCAUUGGUGGUUGAUCCTT-3' \\
3-catenin-siRNA & S: 5'-GGAGAGUACAUUUGCUUUATT-3' \\
& A:5'-UAAAGCAAAUGUACUCUCCTT-3' \\
siRNA-NC & S: 5'-UUCUCCGAACGUGUCACGUTT-3' \\
& A: 5'-ACGUGACACGUUCGGAGAATT-3' \\
miR-33b mimic & S: 5'-GUGCAUUGCUGUUGCAUUGC-3' \\
& A: 5'-AAUGCAACAGCAAUGCACUU-3' \\
miRNA mimic NC S: 5'-UUCUCCGAACGUGUCAGCUTT-3' & A:5'-ACGUGACACGUUCGGAGAATT-3'
\end{tabular}

$\mathrm{S}$, sense; A, antisense.

and induction of NSCLC cell growth (11-13). Furthermore, altered activity of the $\mathrm{WNT} / \beta$-catenin signaling pathway also plays an important role in the development of EMT and cancer metastasis (14). The WNT/ $\beta$-catenin pathway can be activated by inhibition of GSK3 phosphorylation, which in turn suppresses $\beta$-catenin degradation to facilitate the EMT process (15). Overexpression of $\mathrm{WNT} / \beta$-catenin pathway genes was associated with poor NSCLC prognosis (16-19). In addition, altered microRNA (miRNA) expression has been associated with lung carcinogenesis and metastasis (20-22), which is a novel target for cancer therapy. MicroRNA is a class of endogenous, non-coding RNA molecules, which are 18-22 nucleotides long and post-transcriptionally regulate gene expression $(23,24)$. Thus, miRNAs can modulate a variety of biological processes, including cell proliferation, apoptosis, migration, invasion, drug resistance and stem cell maintenance (25-28). Our previous study demonstrated that altered miR-33b expression was involved in lung adenocarcinoma cell EMT (29). In the present study, we further investigated the molecular mechanisms by which miR-33b regulates the expression and activity of ZEB1 and WNT/ $\beta$-catenin pathway genes and their clinical relevance. We sought to establish a functional link between miR-33b and ZEB1, unveiling their role in lung adenocarcinoma progression. We provide evidence that miR-33b may be used as a novel therapeutic strategy to target the oncogenic WNT/ $\beta$-catenin /ZEB1 pathway in lung adenocarcinoma.

\section{Materials and methods}

Cell lines and tissue specimens. Lung cell lines HBE, A549, H1299, SPC- $\alpha-1$, PC-9, LIEP- $\alpha-2$ and HTB182 were purchased from the American Type Culture Collection (ATCC; Manassas, VA, USA) and cultured in RPMI-1640 medium supplemented with $10 \%$ fetal calf serum (FCS; Invitrogen, Carlsbad, CA, USA), $100 \mathrm{IU} / \mathrm{ml}$ penicillin and $100 \mathrm{IU} / \mathrm{ml}$ streptomycin at $37^{\circ} \mathrm{C}$ in a humid atmosphere with $5 \% \mathrm{CO}_{2}$.

Tissue samples from 45 cases of histology-confirmed lung adenocarcinoma were obtained from the Cardiothoracic Surgery Department of Xingya Hospital, Central South
University (Hunan, China). The patients had never received radiation therapy or chemotherapy before surgery and pathologically confirmed as lung adenocarcinoma. The present study was approved by the Ethics Committee of Xiangya Hospital and written informed consent was obtained from each patient before the participation.

Construction of gene expression vectors, lentivirus production and cell infection. Small interfering RNAs (siRNAs) targeting expression of ZEB1 and $\beta$-catenin as well as miR-33b mimic and miRNA mimic NC were synthesized by Shanghai GenePhama Co., Ltd. (Shanghai, China). Unrelated sequences were used as a negative control and were provided by Shanghai GenePhama (Table I). The miR-33b was generated by lentiviral transduction (Shanghai Genechem Co., Ltd., Shanghai, China). The sequences are listed in Table II. Each recombinant lentivirus was purified by ultracentrifugation and titer of these viral particles was assessed for multiplicity of infection (MOI). Similarly, miR-33b mimic and miRNA mimic NC were named as pGC-FU-miR-33b and pGC-FUNC-LV, respectively. The anti-miR-33b and negative control were named as pFU-GW-miR-33b and pFU-GW-RANI-NC, respectively.

Lung cell lines were grown overnight and then infected with different lentiviral MOIs (20 for A549 and 2 for H1299) for 24,48 and $72 \mathrm{~h}$. The cells were then subjected to different assays.

Tumor cell viability. Lung cancer A549 and H1299 cells were seeded into 96-well plates and then infected with different lentiviruses overnight. The cells were grown for $0,24,48,72$ and $96 \mathrm{~h}$ and then subjected to the 3-(4,5-dimethylthiazol2-yl)-2,5-diphenyltetrazolium bromide (MTT) assay. Briefly, the cell culture was supplemented with $20 \mu \mathrm{l}$ of $0.5 \mathrm{mg} / \mathrm{ml}$ of MTT and cells were incubated for $4 \mathrm{~h}$ at $37^{\circ} \mathrm{C}$. Next, the culture medium was replaced with $200 \mu 1$ of dimethyl sulfoxide to dissolve the precipitates for $20 \mathrm{~min}$ at the room temperature. The optical density was measured at $490 \mathrm{~nm}$ using a multi-well plate reader. The experiments were performed in triplicate and repeated at least three times. Data are summarized as mean $\pm \mathrm{SE}$ and normalized as $\%$ of control experiments.

Transwell migration and invasion assay. Lung cells $\left(1 \times 10^{4}\right)$ in serum-free medium were plated in the top chamber of each Transwell insert (Corning Costar, Corning, NY, USA). The complete growth medium was added to the bottom chambers and cells were grown for $24 \mathrm{~h}$ at $37^{\circ} \mathrm{C}$. At the end of experiments, cells that remained in the upper chambers were removed using a cotton swab. The cells that migrated or invaded to the bottom chambers and attached to the lower surface of the membrane were fixed and stained with a dye solution containing $20 \%$ methanol violet and $0.1 \%$ crystal violet and counted under a microscope.

Transwell filter without Matrigel (BD Biosciences, Bedford MA, USA) was used for migration assay, while Transwell filter coated with Matrigel was used for tumor cell invasion assay.

RNA isolation and quantitative RT-PCR. Total RNA from A549 and H1299 cells was isolated using the TRIzol reagent (Invitrogen) and reversely transcribed into cDNA using the 
Table II. Lentiviral sequences.

Lentiviral

Pri-miR-33b

Anti-miR-33b

Anti-miR-NC
Lentiviral sequences

\begin{abstract}
Forward:5'-GGATCCCTTTGGAGGCCCTGCATCAGGAGGGCTGGACAGCTGCTCCCGGGCCGGTGGC GGGTGTGGGGGCCGAGAGAGGCGGGCGGCCCCGCGGTGCATTGCTGTTGCATTGCACGTGTGTGA GGCGGGTGCAGTGCCTCGGCAGTGCAGCCCGGAGCCGGCCCCTGGCACCACGGGCCCCCATCCTG CCCCTCCCAGAGCTGGAGCCCTGGTGACCCCTGCCCTGCCTGCCACCCCCAGGCCGTGCAGCTGT TCCTGTGTGACCTGC-3'
\end{abstract}

Reverse: 5'-GCAGGTCACACAGGAACAGCTGCACGGCCTGGGGGTGGCAGGCAGGGCAGGGGTCA CAGGGCTCCAGCTCTGGGAGGGGCAGGATGGGGGCCCGTGGTGCCAGGGGCCGGCTCCGGGCTG CACTGCCGAGGCACTGCACCCGCCTCACACACGTGCAATGCAACAGCAATGCACCGCGGGGCCG CCCGCCTCTCTCGGCCCCCACACCCGCCACCGGCCCGGGAGCAGCTGTCCAGCCCTCCTGATGCA GGGCCTCCAAAGGGATCC-3'

\section{Forward: 5'-GTGCATTGCTGTTGCATTGC-3'}

Reverse: 5'-GCAATGCAACAGCAATGCAC-3'

Forward: 5'-TTCTCCGAACGTGTCACGT-3'

Reverse: 5'-ACGTGACACGTTCGGAGAA-3'
Table III. Study primers.

\begin{tabular}{|c|c|}
\hline Genes & Primers 5'-3' \\
\hline \multicolumn{2}{|l|}{ Human } \\
\hline GAPDH & $\begin{array}{l}\text { F: 5'-AGGGCTGCTTTTAACTCTGGT-3' } \\
\text { R: 5'-CCCCACTTGATTTTGGAGGGA-3 }\end{array}$ \\
\hline ZEB1 & $\begin{array}{l}\text { F: 5'-CTGCCCAGTTACCCACAATC-3' } \\
\text { R: 5'-CAGGGCTGACCGTAGTTGAG-3' }\end{array}$ \\
\hline Vimentin & $\begin{array}{l}\text { F: 5'-GTACCGGAGACAGGTGCAGT-3' } \\
\text { R: 5'-AACGGCAAAGTTCTCTTCCA-3' }\end{array}$ \\
\hline E-cadherin & $\begin{array}{l}\text { F: 5'-GGGTTATTCCTCCCATCAGC-3' } \\
\text { R: 5'-GTCACCTTCAGCCATCCTGT-3' }\end{array}$ \\
\hline$\beta$-catenin & $\begin{array}{l}\text { F: 5'-GCTTTCAGTTGAGCTGACCA-3 } \\
\text { R: 5'-CAAGCTCAAGATCAGCAGTCTC-3 }\end{array}$ \\
\hline \multicolumn{2}{|l|}{ Mouse } \\
\hline GAPDH & $\begin{array}{l}\text { F: 5'-AACTTTGGCATTGTGGAAGG-3' } \\
\text { R: 5'-TGTGAGGGAGATGCTCAGTG-3' }\end{array}$ \\
\hline ZEB1 & $\begin{array}{l}\text { F: 5'-GTGTGCCTGAACCTCAAACC-3' } \\
\text { R: 5'-AGCCTCCTGTAACCTGCTGA-3' }\end{array}$ \\
\hline Vimentin & $\begin{array}{l}\text { F: 5'-CGCAGCCTCTATTCCTCATC-3' } \\
\text { R: 5'-AGCGAGAAGTCCACCGAGT-3' }\end{array}$ \\
\hline E-cadherin & $\begin{array}{l}\text { F: 5'-TCTCTTGTCCCTTCCACAGC-3' } \\
\text { R: 5'-TTCCTGACCCACACCAAAGT-3' }\end{array}$ \\
\hline$\beta$-catenin & $\begin{array}{l}\text { F: 5'-TGGTGACAGGGAAGACATCA-3' } \\
\text { R: 5'-CCACAACAGGCAGTCCATAA-3' }\end{array}$ \\
\hline
\end{tabular}

F, forward; R, reverse.

All-in-One ${ }^{\mathrm{TM}}$ First Strand cDNA Synthesis kit (AORT-0050; GeneCopoeia, Shanghai, China) and miRNA First Strand cDNA Synthesis kit (AMRT-0050; GeneCopoeia) according to the manufacturer's instructions. qPCR amplification was performed using the All-in-One ${ }^{\mathrm{TM}}$ qPCR mix (AOPR-1200; GeneCopoeia) and the All-in-One ${ }^{\mathrm{TM}}$ miRNA qRT-PCR detection kit (AOMD-Q050; GeneCopoeia) on an ABI 7300HT real-time PCR system (Applied Biosystems, Foster City, CA, USA). The qPCR cycle was set to an initial $95^{\circ} \mathrm{C}$ for $5 \mathrm{~min}$, 40 cycles of $95^{\circ} \mathrm{C}$ for $15 \mathrm{sec}, 60^{\circ} \mathrm{C}$ for $30 \mathrm{sec}$, and a final meltcurve analysis $\left(60-95^{\circ} \mathrm{C}\right)$. Primers used for qPCR are listed in Table III. U6 was used as the endogenous control to normalize miRNA level, while GAPDH mRNA was used to normalize mRNA levels using the $2^{-\triangle \Delta C T}$ method. Primers for miR-33b (HmiRQP0432) and U6 (HmiRQP900) were purchased from GeneCopoeia.

Protein extraction and western blot analysis. Total cellular protein was extracted using a lysis buffer containing $50 \mathrm{mM}$ Tris (pH 7.4), $150 \mathrm{mM} \mathrm{NaCl}$, and $1 \% \mathrm{NP}-40$. BCA protein assay kit (Pierce, Rockford, IL, USA) was used to determine concentration of the protein samples. Western blotting was conducted according to a previous study (30) with the following primary antibodies: ZEB1 (NBP2-23484; Novus Biologicals, Littleton, CO, USA, at a dilution of 1:800), vimentin (D21H3, 1:1,000; Cell Signaling Technology, Danvers, MA, USA), E-cadherin (ab76055, 1:1,000; Abcam, Cambridge, MA, USA), $\beta$-catenin (D10A8, 1:1,000; Cell Signaling Technology), GAPDH (14C10, 1:1,000; Cell Signaling Technology), and secondary goat anti-rabbit and goat anti-mouse $(1: 5,000)$ immunoglobulin $G$ (Invitrogen).

Immunohistochemistry. Paraffin sections were obtained from the Xiangya Hospital of The Central South University and used for immunostaining expression of different proteins according to a protocol provided by Beijing Zhongshan Golden Bridge Biotechnology Co., Ltd. (Beijing, China). Negative control sections were incubated with normal goat serum to replace the primary antibody (ZEB1, vimentin, E-cadherin and $\beta$-catenin). All primary antibodies were used at a dilution of 1:200. The immunostained tissue sections were then reviewed 
Table IV. Association of miR-33b expression with patients' clinicopathological features.

\begin{tabular}{lrrrrr}
\hline & \multicolumn{5}{c}{$\begin{array}{c}\text { miR-33b } \\
\text { expression }\end{array}$} \\
Features & $\begin{array}{c}\text { No. of } \\
\text { patients }\end{array}$ & Low & High & & \\
\hline Age (years) & & & & & P-value \\
$\leq 60$ & 28 & 20 & 8 & & \\
$>60$ & 17 & 12 & 5 & 0.003 & 0.95 \\
Gender & & & & & \\
$\quad$ Male & 35 & 24 & 11 & & \\
Female & 10 & 8 & 2 & 0.549 & 0.48 \\
Clinical stage & & & & & \\
$\quad$ I-II & 30 & 23 & 7 & & \\
III-IV & 15 & 10 & 5 & 0.511 & 0.47 \\
Lymph node status & & & & & \\
$\quad+$ & 15 & 12 & 3 & & \\
- & 30 & 14 & 16 & 4.55 & 0.03 \\
\hline
\end{tabular}

and scored under a microscope according to a previous study. Specifically, each sample was scored separately by two pathologists and reviewed until a consensus was reached. Tissue sections without staining or $<5 \%$ staining were scored as 0 ; those with $5-30 \%$ staining as 1 ; with $31-70 \%$ staining as 2 ; and $\geq 71 \%$ staining as 3 . The staining intensity was scored as 0 for negative staining, 1 for weak staining, 2 for moderate staining, and 3 for strong staining. The two scores were then combined to obtain the immunostaining score for each case, i.e., the final score of $0-1$ was considered as negative gene expression (-); 2-3, weak expression (+); 4-5, moderate expression (++); and 6, strong expression (+++) (31).

Immunofluorescence. Lung cells were grown on coverslips and infected with different lentiviruses for $24 \mathrm{~h}$ and then washed with phosphate-buffered saline (PBS) twice and fixed in freshly prepared $4 \%$ paraformaldehyde for $10 \mathrm{~min}$ at room temperature. For immunofluorescence staining, the cells were treated with $0.1 \%$ Triton $\mathrm{X}-100$ for $10 \mathrm{~min}$ to permeabilize cell membrane and further incubated with $1 \% \mathrm{BSA}$ for $1 \mathrm{~h}$ at room temperature. Next, the cells were incubated overnight with a primary antibody against ZEB1, vimentin, E-cadherin, or $\beta$-catenin at a dilution of $1: 100$ at $4^{\circ} \mathrm{C}$. The next day, cells were washed with PBS three times and incubated with a secondary antibody diluted 1:100 in PBS for $1 \mathrm{~h}$ at the room temperature. DAPI was used to visualize the nuclei by incubating cells at room temperature for $10 \mathrm{~min}$. Subsequently, the cells were examined and scored under a fluorescence microscope (Leica Microsystems, Heidelberg, Germany).

Luciferase assay. The wild-type and mutant ZEB1 3'-untranslational region (UTR) luciferase reporters were obtained from Guangzhou RiboBio Co., Ltd. (Guangzhou, China). Human ZEB1 cDNA 3'-UTR region and mutated 3'-UTR region were generated with genomic DNA from 239T cells using PCR with
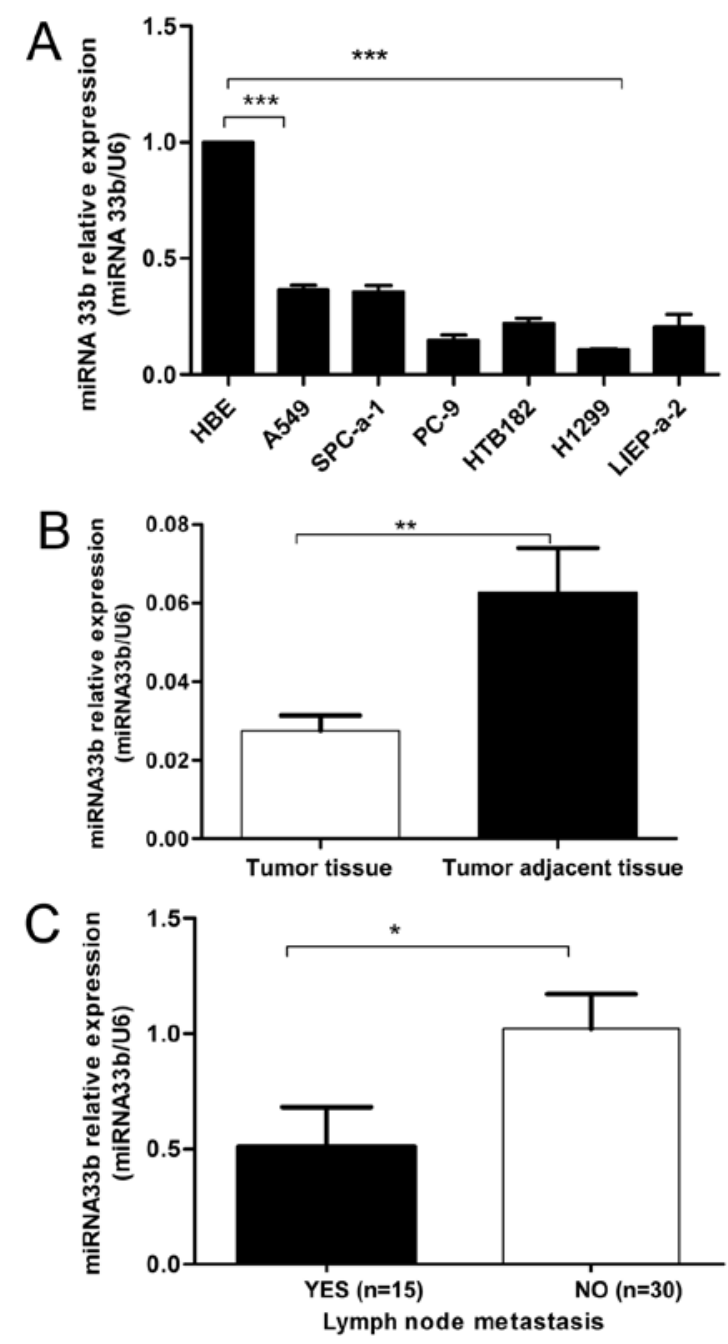

Figure 1. Suppressed miR-33b expression in lung adenocarcinoma cells and tissue specimens. (A) qRT-PCR. The relative level of miR-33b was detected in different NSCLC cell lines. (B) qRT-PCR. The relative expression of miR-33b was detected in 45 primary lung adenocarcinoma tissues and paired adjacent normal tissues. (C) qRT-PCR. The relative expression of miR-33b was detected in lymph node metastatic tumor tissues vs. non-lymph node metastasis. All the data are reported as the mean \pm SD of three independent experiments $\left({ }^{*} \mathrm{P}<0.05,{ }^{* *} \mathrm{P}<0.01\right.$ and ${ }^{* * *} \mathrm{P}<0.01$ using Student's t-test).

the following primers ZEB1-3'-UTR wild-type, 5'-GGCGGC TCGAGATACTTGCCTTGGACTGTAG-3' and 5'-AATGC GGCCGCAGTGAGGAATGTGAGAGTGA-3' or ZEB13'-UTR mutant, 5'-CACAATAATTACGTTCAACAAGCCT GAACTGC-3' and 5'-CTTGTTGAACGTAATTATTGTGAG ATGGGAGT-3', and then cloned into the XhoI and NotI sites of pmiR-RB-REPORT ${ }^{\mathrm{TM}}$ vector (Promega, Madison, WI, USA). After amplification and DNA-sequence confirmation, these vectors were named as pmiR-ZEB1-3'-UTR-wt and pmiR-ZEB1-3'-UTR-mut, respectively. For luciferase assay, HEK-293 cells were grown and co-transfected with these luciferase reporters and miR-33b mimic or a negative control vector for $36 \mathrm{~h}$ using Lipofectamine 2000 (Invitrogen). Subsequently, cells were subjected to protein extraction and the dual luciferase assay system (Promega) to measure the luciferase activity according to the kit instructions. The firefly luciferase activity of each sample was then normalized to Renilla luciferase activity. 

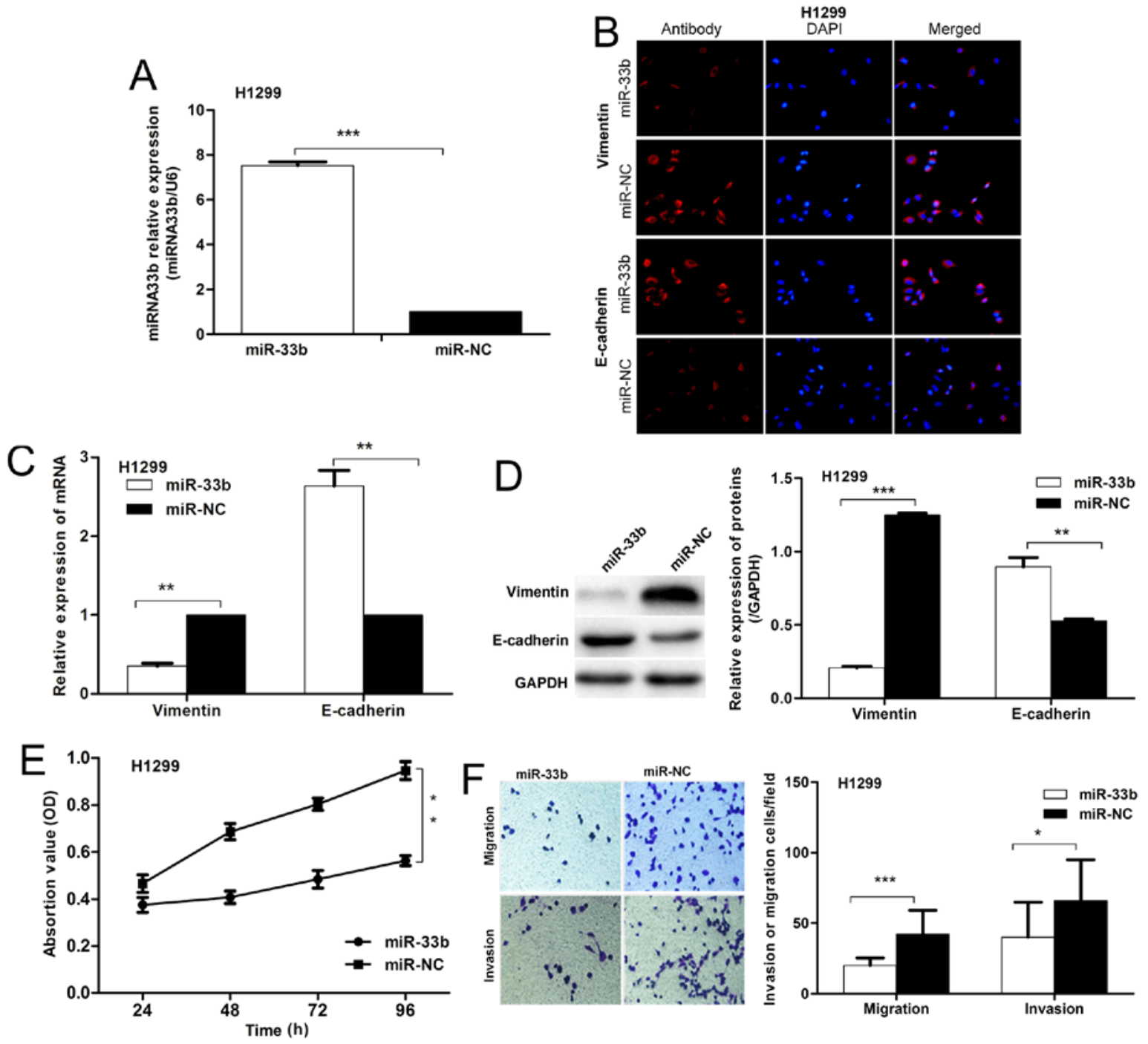

Figure 2. miR-33b suppresses lung adenocarcinoma cell proliferation migration, invasion and EMT in vitro. (A) qRT-PCR. Lung cells were transfected with miR-33b or miR-NC and then subjected to qRT-PCR analysis. (B) Immunofluorescence. Lung cells were transfected with miR-33b or miR-NC and then subjected to immunofluorescent staining. (C) qRT-PCR. Lung cells were transfected with miR-33b or miR-NC and then subjected to qRT-PCR. (D) Western blot analysis. Lung cells were transfected with miR-33b or miR-NC and then subjected to western blot analysis. (E) cell viability MTT assay. Lung cells were transfected with miR-33b or miR-NC and subjected to MTT assay. (F) Transwell migration and invasion assay. Lung cells were transfected with miR-33b or miR-NC and then subjected to Transwell migration and invasion assay (original magnification, $\mathrm{x} 40$ ). All data are summarized as mean \pm SD of three independent experiments $\left({ }^{*} \mathrm{P}<0.05,{ }^{* *} \mathrm{P}<0.01\right.$ and ${ }^{* * *} \mathrm{P}<0.001$ using Student's t-test).

Animal experiments. All mouse experiments were carried out according to the regulations of the Animal Center of Central South University (Hunan, China), which supplied the 4-weekold female BALB/c nude mice. For animal experiments, lung adenocarcinoma H1299 cell line was infected with lentivirus carrying miR-33b or negative control for $36 \mathrm{~h}$ and then injected subcutaneously into the flank region of these nude mice for $1 \times 10^{7}$ in $200 \mu 1$ volume per mouse $(n=6)$. The length (a) and the width (b) of the tumor xenografts in mice were measured. The xenograft volumes were calculated using the formula, $\mathrm{V}\left(\mathrm{mm}^{3}\right)=\mathrm{axb}^{2} / 2$. The mice were sacrificed on day 21 and tumor xenografts were removed, photographed, weighed and sectioned for hematoxylin and eosin (H\&E) staining, immunohistochemistry, qRT-PCR and western blot analysis.

Statistical analysis. All data were summarized as mean \pm SD derived from three independent experiments, unless specifically stated. Comparative data between the groups were analyzed for statistical significance using the two-tailed paired Student's t-test. Comparison of categorical variables between the groups was statistically analyzed using the $\chi^{2}$ test. Pearson's test was performed to calculate the association between miR-33b and ZEB1 expression. $\mathrm{P}<0.05$ was considered statistically significant.

\section{Results}

Reduced miR-33b expression in lung adenocarcinoma cells and tissue specimens. We first assessed miR-33b expression in NSCLC cell lines and found that the levels of miR-33b were significantly reduced in NSCLC cell lines compared with those of normal bronchial epithelium HBE cells (Fig. 1A). We then analyzed miR-33b expression in 45-paired primary lung adenocarcinoma and distant normal tissues (at least $5 \mathrm{~cm}$ distal to the tumor lesion). Compared with normal tissues, lung adenocarcinoma tissues expressed much lower levels 

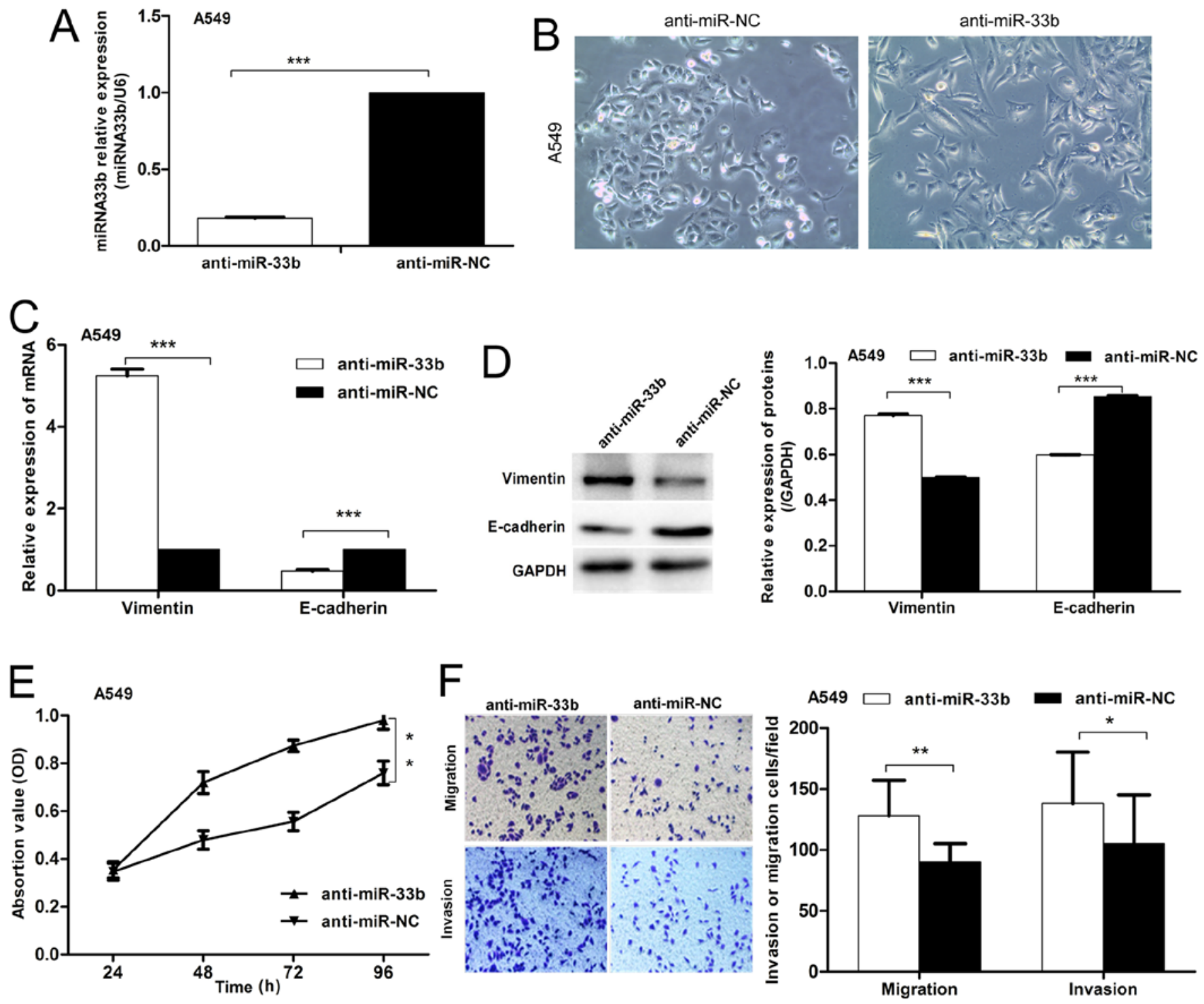

Figure 3. Knockdown of miR-33b promotes lung adenocarcinoma cell proliferation, migration, invasion and EMT in vitro. (A) qRT-PCR. Lung A549 cells were transfected with anti-miR-33b or anti-miR-NC and then subjected to qRT-PCR analysis of miR-33b expression. (B) Cell morphology. Lung A549 cells were transfected with anti-miR-33b or anti-miR-NC and cell morphology was photographed (original magnification, x10). (C and D) qRT-PCR or western blot analysis. Lung A549 cells were transfected with anti-miR-33b or anti-miR-NC and then subjected to qRT-PCR or western blot analyses of vimentin, E-cadherin expression. (E and F) A549 cells were transfected with the anti-miR-33b or the anti-miR-NC were subjected to MTT and Transwell assays (original magnification, $\mathrm{x} 40$ ) to analyze growth curves, migration and invasion, respectively. All data are summarized as mean \pm SD of three independent experiments $\left(\right.$ $\mathrm{P}<0.05,{ }^{* *} \mathrm{P}<0.01$ and ${ }^{* * * *} \mathrm{P}<0.001$ using Student's t-test).

of miR-33b ( $0.033 \pm 0.027$ vs. $0.073 \pm 0.061, \mathrm{P}<0.01$; Fig. $1 \mathrm{~B})$. We then associated miR-33b expression with the patient clinicopathological features and found that reduced miR-33b expression was associated with tumor lymph node metastasis, but not with age, gender, or tumor stage (Fig. 1C and Table IV).

Effects of miR-33b restoration on suppression of lung adenocarcinoma cell proliferation, invasion and migration in vitro and tumor cell EMT. We then assessed the effects of miR-33b restoration on suppression of lung adenocarcinoma cell proliferation, migration, and invasion and tumor cell EMT in vitro by infected H1299 cells with miR-33b mimics and miR-NC. The data showed high transfection efficiency and restored miR33b expression in the infected cells (Fig. 2A). miR-33b upregulated E-cadherin expression. However, the expression of vimentin, another marker of mesenchymal phenotype, was decreased (Fig. 2B-D). The miR-33b restoration in lung cancer cells significantly reduced tumor cell viability (Fig. 2E) and migration and invasion capacity (Fig. 2F). In contrast, knockdown of miR-33b expression promoted lung adenocarcinoma cell proliferation, invasion and migration and EMT in vitro (Fig. 3).

ZEBI as the miR-33b-targeting gene in lung cancer cells. MicroRNA regulates the expression of protein-coding genes in cells. Therefore, we explored the molecular mechanism by which miR-33b suppressed lung cancer metastasis. We first performed gene target analysis using online tools (miRanda and miRbase) to identify potential miR-33b-binding genes and found that miR-33b binds to ZEB1 3'-UTR region 

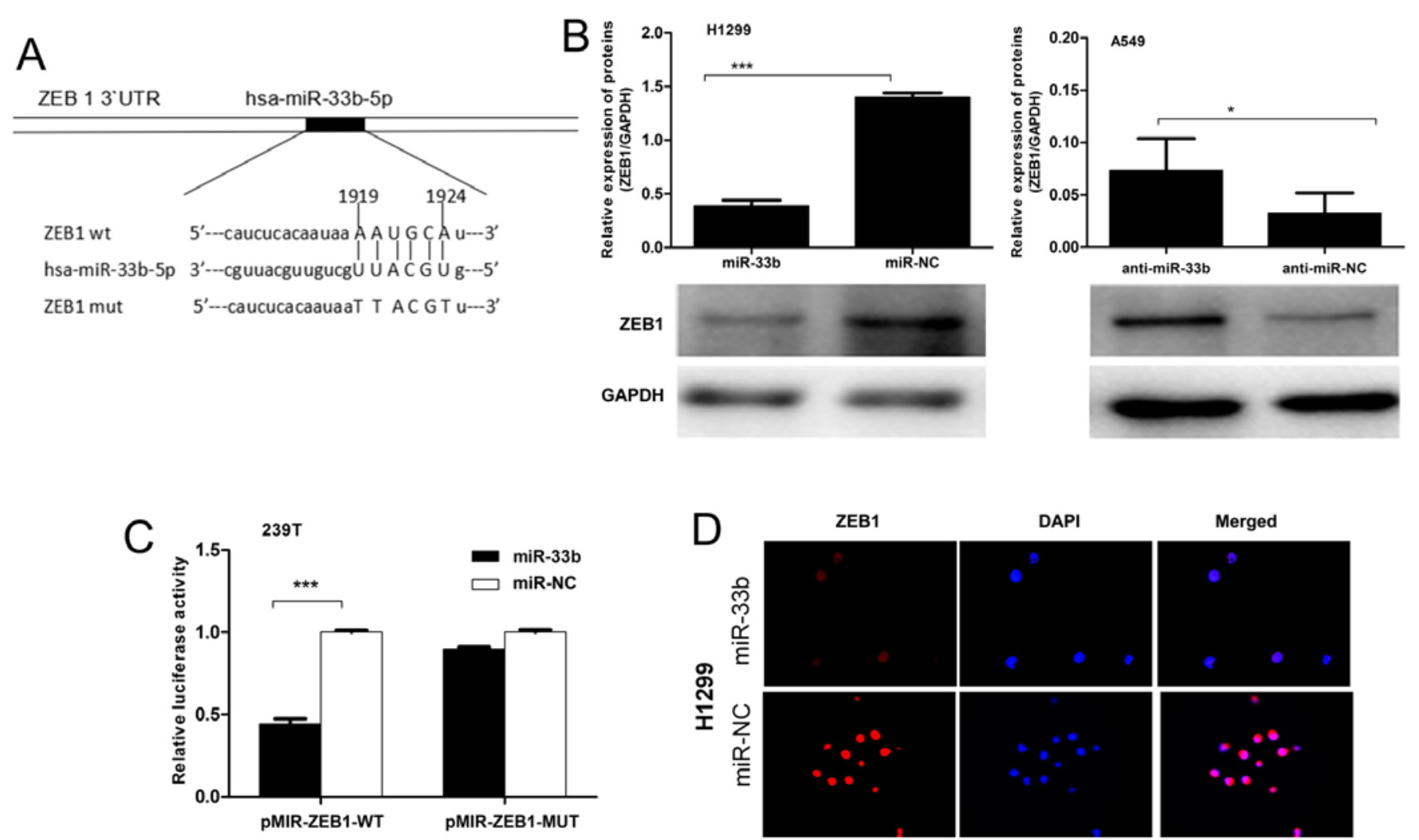

Figure 4. miR-33b directly targeted ZEB1 expression. (A) Illustration of miR-33b targeting sequences of ZEB1 3'-UTR or mutations containing six mutant sites in ZBE1 3'-UTR used for luciferase assay (ZEB1-mut). (B) Western blot analysis. ZEB1 expression was assayed in lung adenocarcinoma cells after transfection with miR-33b or miR-NC, anti-miR-33b or anti-miR-NC in H1299 and A549 cells. (C) Luciferase activity. HEK239T cells were transfected with miR-33b site mutant 3'-UTR-driven reporter constructs; wt, wild-type (n=3). (D) Immunofluorescence. Expression of ZEB1 protein was assayed in lung adenocarcinoma cells after transfection with miR-33b or miR-NC. Error bars represent SEM of three independent experiments $\left({ }^{*} \mathrm{P}<0.05,{ }^{* *} \mathrm{P}<0.01\right.$ and ${ }^{* * *} \mathrm{P}<0.001 \mathrm{using}$ Student's t-test).

(Fig. 4A). We then validated it using several different experiments. First, we associated miR-33b with ZEB1 expression in lung adenocarcinoma cell lines transfected with miR-33b, miR-NC, anti-miR-33b and anti-miR-NC. We found that miR-33b overexpression significantly reduced ZEB1 expression in the cells, whereas knockdown of miR-33b expression significantly upregulated ZEB1 expression (Fig. 4B). We then constructed a luciferase reporter plasmid carrying ZEB1 3'-UTR (Fig. 4C). The luciferase activity was significantly decreased in the Luc-ZEB1-3'-UTR-transfected cells compared with that of the potential target site of mutant miR-33b in ZEB1 3'-UTR and negative control cells. In addition, immunofluorescence showed exclusive expression and cellular localization of ZEB1 protein in H1299 cells (Fig. 4D).

miR-33b expression inversely associates with ZEBI expression. Furthermore, we analyzed the expression of ZEB1 mRNA in additional lung adenocarcinoma cell lines (Fig. 5A) and in paired lung cancer and normal tissue specimens. Expression of ZEB1 mRNA in normal and cancerous tissues was $0.084 \pm 0.11$ and $0.319 \pm 0.12$, respectively; $\mathrm{P}<0.001$; Fig. 5B). We then associated the expression of ZEB1 mRNA and miR-33b in tissue samples and found an inverse correlation in lung adenocarcinoma tissues $(r=-0.9086, \mathrm{P}<0.001$; Fig. 5C). These data implied that miR-33b targeted ZEB1 expression in lung cancer cells. Furthermore, our immunostaining data involving tissue samples also showed that expression of ZEB1 protein was upregulated in lung adenocarcinoma tissues and lymph node metastasized tumor tissues compared with that of distant normal tissues $(\mathrm{P}<0.01$; Fig. $5 \mathrm{D})$.

In addition, we co-infected siRNA-NC, ZEB1-siRNA, and anti-miR-33b in the lung cancer A549 cell line. The data confirmed the infection efficiency using western blot analyses of their protein expression after lentivirus infection (Fig. 5E). Furthermore, knockdown of ZEB1 expression in A549 cells using ZEB1 siRNA resulted in decrease in tumor cell proliferation, migration, and invasion (Fig. 5F and G), whereas induction of ZEB1 expression after miR-33b knockdown induced tumor cell proliferation, migration and invasion (Fig. 5F and G). Taken altogether, our data indicate that miR-33b targets ZEB1 expression by binding to ZEB1 3'-UTR region to modulate proliferation, migration and invasion of lung adenocarcinoma cells.

miR-33b regulated the WNT/ $\beta$-catenin signaling in lung adenocarcinoma cells. Previous studies demonstrated that the $W N T / \beta$-catenin signaling is activated in NSCLC cell lines (32). Activated WNT/ $\beta$-catenin signaling promoted the growth of lung cancer cells regulated by miR-21 (33). Thus, in the present study, we assessed the role of miR-33b in lung cancer cells or tissues via modulation of $\mathrm{WNT} / \beta$-catenin 

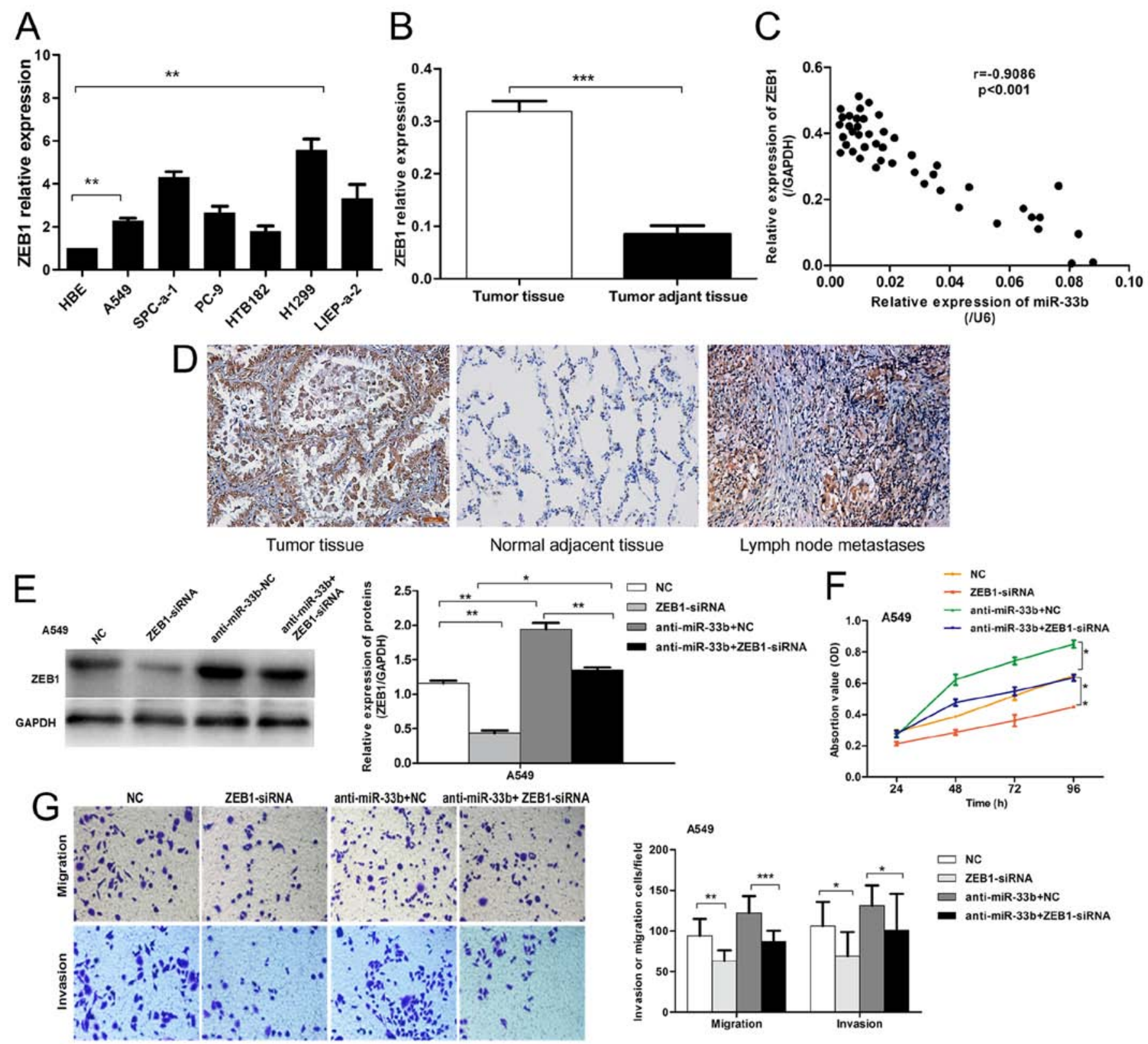

Figure 5. Inverse association of miR-33b expression with ZEB1 mRNA levels in lung adenocarcinoma cells and tissue specimens. (A and B) qRT-PCR. Expression of ZEB1 was analyzed in lung NSCLC cells and tissues, respectively. (C) The inverse association between miR-33b and ZEB1 mRNA levels in lung adenocarcinoma was statistically analyzed using Pearson's correlation coefficient. (D) Immunohistochemistry. Expression of ZEB1 was detected in lung adenocarcinoma, normal lung tissue and lymph node metastases immunohistochemically (original magnification, x20). (E) Western blot analysis. Level of ZEB1 protein was measured in lung cells after gene transfection. (F) Cell viability MTT assay. Growth curves of lung adenocarcinoma cells with different treatments were analyzed. (G) Tumor cell Transwell migration or invasion assay. Lung adenocarcinoma cells with different treatments were detected. All data are summarized as mean $\pm \mathrm{SD}$ of three independent experiments $\left({ }^{*} \mathrm{P}<0.05,{ }^{* *} \mathrm{P}<0.01\right.$ and ${ }^{* * * *} \mathrm{P}<0.001$ using Student's t-test).

pathway activity. We infected lung cancer A549 and H1299 cells with lentivirus carrying miR-33b, miR-NC, anti-miR-33b or anti-miR-NC. Our data showed that miR-33b overexpression significantly decreased $\beta$-catenin expression, whereas miR-33b knockdown increased $\beta$-catenin expression (Fig. 6A and $\mathrm{B}$ ).

Furthermore, we co-transfected $\beta$-catenin siRNA, siRNANC, and anti-miR-33b in A549 cells (Fig. 6C). We found that knockdown of $\beta$-catenin expression decreased proliferation and invasion of A549 cells, whereas anti-miR-33b-upregulated $\beta$-catenin promoted A549 cell proliferation and invasion (Fig. 6D and E). Taken together, these results indi- cated that miR-33b expression may regulate the activity of WNT/ $\beta$-catenin signaling.

miR-33b inhibition of tumor cell growth and EMT by suppression of the Wnt/ß-catenin/ZEB1 pathway activity in vivo. After demonstrating the role of miR-33b in lung cancer cells by targeting ZEB1 expression and suppressing activity of the Wnt/ $\beta$-catenin/ZEB1 pathway in vitro, we assessed the effects of miR-33b on tumor growth using the in vivo nude mouse xenograft assay. Our data showed that the mean volume of miR-33b-H1299 cell xenograft tumors was significantly smaller than that of control cell xenografts (Fig. 7A and B). 

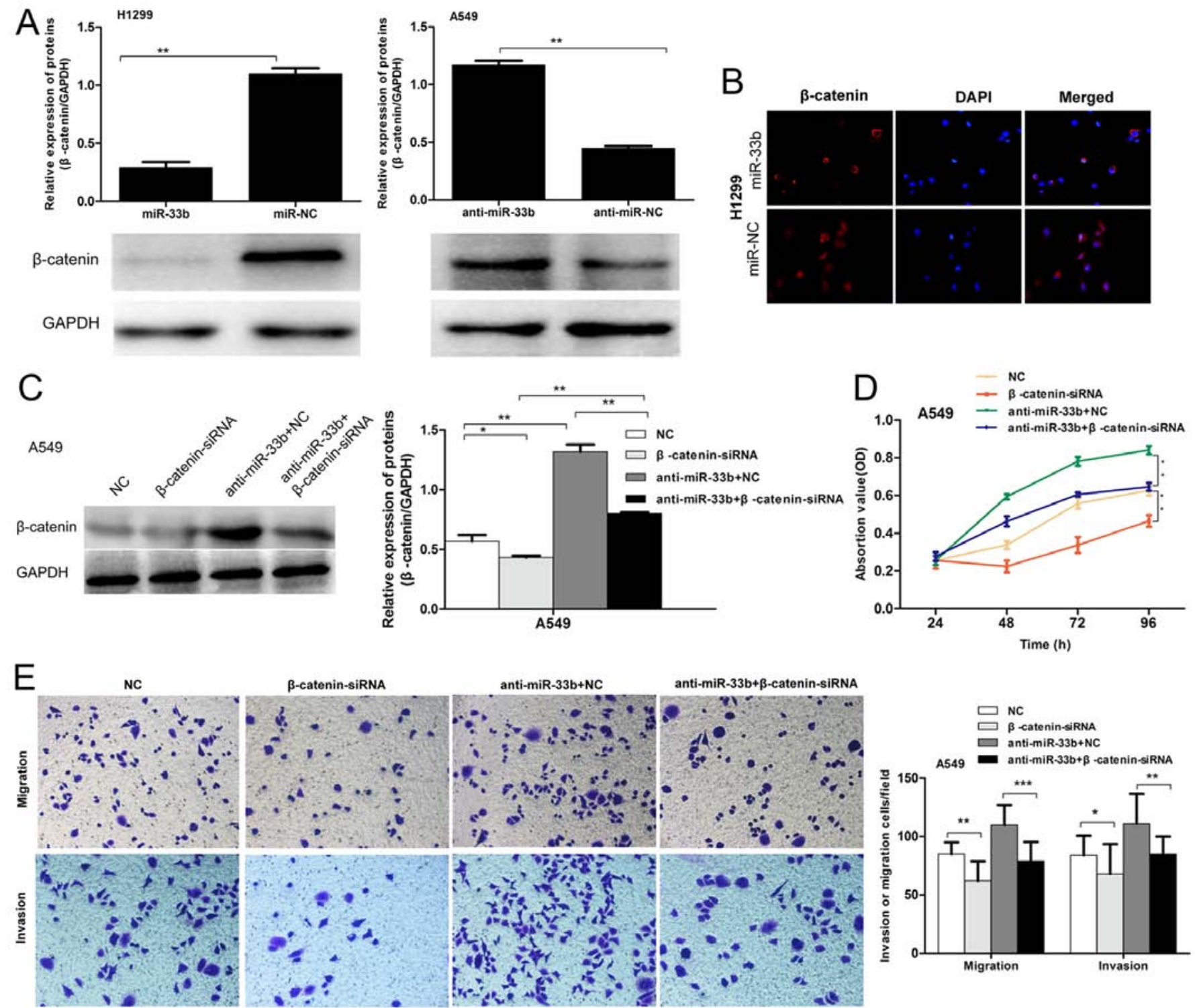

Figure 6. miR-33b regulated WNT/ $\beta$-catenin signaling in lung adenocarcinoma cells. (A and B) Western blot analysis and immunofluorescence. Expression of $\beta$-catenin was assayed in lung adenocarcinoma cells. (C) Western blot analyis. Expression of $\beta$-catenin protein was assayed in lung cells after gene transfections. (D) Cell viability MTT assay. Growth curves of lung adenocarcinoma cells with different treatments were analyzed. (E) Tumor cell Transwell migration or invasion assay. Lung adenocarcinoma cells with different treatments were detected. All data are summarized as mean \pm SD of three independent experiments $\left({ }^{*} \mathrm{P}<0.05,{ }^{* *} \mathrm{P}<0.01\right.$ and ${ }^{* * *} \mathrm{P}<0.001$ using Student's t-test).

Immunohistochemistry revealed that the expression of ZEB1, vimentin, E-cadherin and $\beta$-catenin genes was consistent with our in vitro data (Fig. 7C). In brief, expression of ZEB1, $\beta$-catenin and Vimentin proteins was downregulated, whereas E-cadherin levels were upregulated in miR-33b-overexpressed lung cancer cell xenografts. The western blot data further confirmed immunostaining data (Fig. 7D and E) demonstrating that miR-33b overexpression inhibited tumor growth, EMT and the Wnt/ $\beta$-catenin pathway activity in vivo.

\section{Discussion}

The present study was based on our previous data involving altered miR-33b expression in the regulation of lung adenocarcinoma cell EMT (29). We supposed that miR-33b regulated the WNT/ $\beta$-catenin pathway activity by targeting ZEB1 expression to suppress lung adenocarcinoma growth, invasion, and EMT. Indeed, our current data showed that: i) the expression of miR-33b and ZEB1 was inversely correlated in lung adenocarcinoma cells and tissues; ii) miR-33b bound to ZEB1 3'-UTR region; iii) expression of miR-33b downregulated ZEB1 expression, while knockdown of miR-33b expression upregulated ZEB1 expression; iv) knockdown of ZEB1 expression using siRNA markedly inhibited lung adenocarcinoma invasion and migration, effects of which were similar to miR-33b overexpression in lung cancer cells in vitro; and v) miR-33 overexpression also inhibited $\mathrm{WNT} / \beta$-catenin pathway activity, whereas knockdown of miR-33b expression induced WNT/ $\beta$-catenin pathway activity in lung cancer cells in vitro and in vivo. Thus, these findings provide novel insight into the molecular mechanism of miR-33b in suppressing lung adenocarcinoma metastasis. Additional studies are needed to 
A

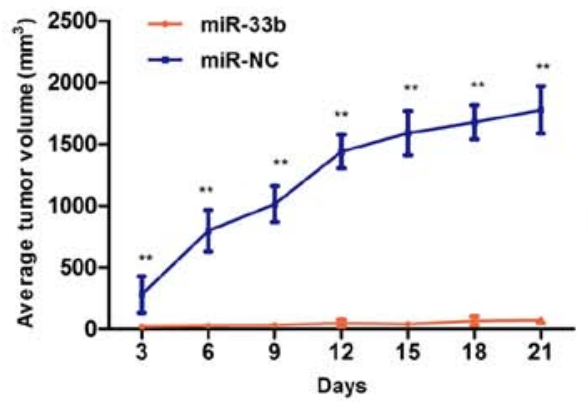

C miR-NC

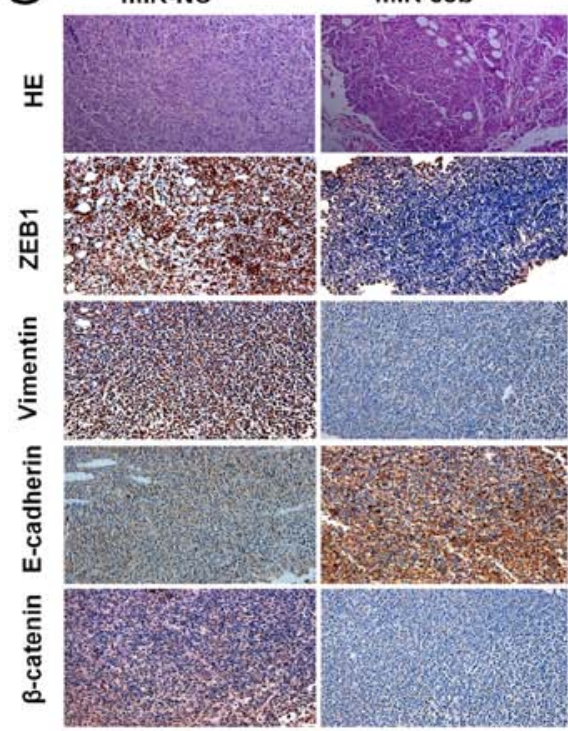

B

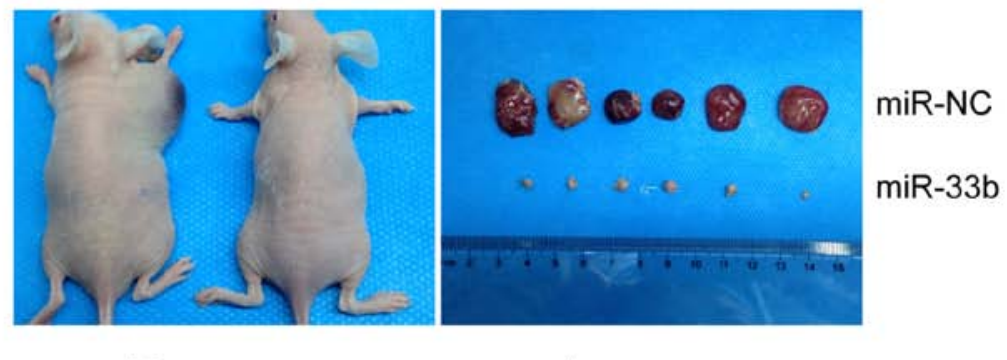

$\mathrm{D}$
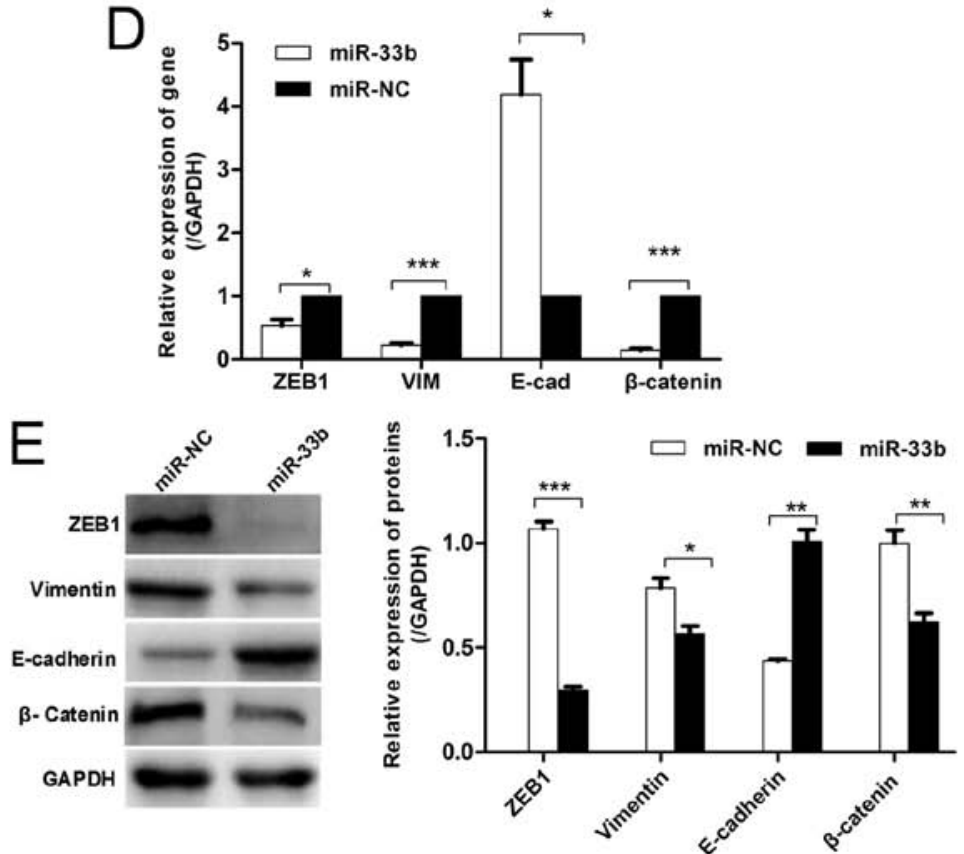

Figure 7. miR-33b inhibits lung cancer xenograft growth and EMT via Wnt/B-catenin/ZEB1 pathway activity in vivo. (A and B) Tumor xenograft growth curves in mice (n=6 per group). $\mathrm{H} 1299$ cells were inoculated into nude mice for indicated days. At the experimental end point, tumor xenografts were dissected and photographed. (C) Hematoxylin and eosin (H\&E) and immunostaining. Tumor xenografts were processed and stained with HE and immunohistochemically for ZEB1, vimentin, E-cadherin and $\beta$-catenin and then quantified according to staining intensity. (D and E) qRT-PCR and western blot analysis. Levels of ZEB1, vimentin, E-cadherin, $\beta$-catenin mRNA and protein were analyzed in tumor xenografts. All data are summarized as mean \pm SD of three independent experiments $\left({ }^{*} \mathrm{P}<0.05,{ }^{* *} \mathrm{P}<0.01\right.$ and ${ }^{* * *} \mathrm{P}<0.001$ using Student's t-test).

assess whether restoration of miR-33b expression is a novel strategy in the control of lung adenocarcinoma preclinically and clinically.

Indeed, lung cancer remains the most common cause of cancer-related death in the world and lung adenocarcinoma is one of the main NSCLC pathological types (34). Cancer metastasis accounts for nearly $90 \%$ of lung adenocarcinomarelated deaths (35). Thus, effective control of cancer metastasis by blocking tumor cell EMT could be a key molecular mechanism. Our current data showed that reduced miR-33b expression led to lung adenocarcinoma cell EMT, which is consistent with a previous study showing that altered miRNA expression plays a crucial role in cancer metastasis (36). Furthermore, our previous study of miRNA-mediated TGF- $\beta 1$ induced EMT using the miRNA chips assay (29) revealed that miR-33b mediated TGF- $\beta 1$-induced EMT in lung cancer cells. The present study showed that miR-33b was downregulated in lung adenocarcinoma cells and tissues, which associated with tumor lymph node metastasis, further suggesting the role of miR-33b in lung adenocarcinoma progression. miR-33b is localized within intron 17 of sterol regulatory element-binding protein 1 (Srebp-1) gene on chromosome 17 (37). A previous study demonstrated that upregulation of miR-33b expression arrested lung cancer A549 cells at the G1 phase of the cell cycle (38), while Takwi et al (39) showed that lovastatin-upregulated miR-33b reduced medulloblastoma cell proliferation and reduced c-Myc expression. In this study, we found that miR-33b overexpression inhibited lung cancer cell growth, migration and invasion.

Moreover, the present study revealed that miR-33b binds to 3'-UTR region of ZEB1 cDNA and suppressed ZEB1 protein expression in lung cancer cell lines. ZEB1 is a transcriptional factor that was originally shown to repress interleukin (IL)-2 expression via binding to a negative regulatory domain in IL-2 promoter (40). IL-2 is a cytokine regulating the host immune response via cells such as leukocytes and lymphocytes against microbial infection. IL-2 has been approved by US FDA and several European countries for treatment of different human cancers (41-43). A recent study reported that ZEB1 had a contributing role in lung cancer invasiveness and metastasis (44). Indeed, ZEB1 protein was expressed in a variety of cancers, such as colon cancer (45), NSCLC (46), 
bladder (47), breast (48), pancreatic cancer (49) and esophageal squamous carcinoma (50). ZEB1 regulates the EMT and promotes cancer metastasis. For example, the ectopic ZEB1 expression was sufficient to induce EMT by downregulating E-cadherin expression in breast cancer cells (51). Thus, this study showed that ZEB1 expression was attributed to recued miR-33b expression in cancer cells, at least in lung adenocarcinoma cells.

Overexpression of $\mathrm{Wnt} / \beta$-catenin pathway proteins, like WNT1, WNT3A, WNT5A, and/or $\beta$-catenin, was associated with poor prognosis of NSCLC patients (16-19). In surgical NSCLC tissues, Wnt-1 was positively expressed in $37-63 \%$ of samples $(18,52,53)$. Activated WNT/ $\beta$-catenin signaling promoted tumor cell EMT in colorectal cancer (54), while another study showed that reduced miR-200a promoted gastric cell EMT and growth via the $\mathrm{Wnt} / \beta$-catenin pathway by targeting ZEB1/ZEB2 expression (31). In the present study, we demonstrated that miR-33b suppressed activity of the Wnt/ $\beta$-catenin pathway and in turn, inhibited lung adenocarcinoma cell growth, migration, invasion, and expression of EMT markers. Thus, our current data revealed a novel mechanism by which The Wnt/ $\beta$-catenin signaling contributing to lung cancer metastasis.

Taken together, the present results outline a possible role and mechanism of miR-33b in suppression of lung adenocarcinoma progression by identifying that reduced miR-33b expression promoted ZEB1 expression and in turn, activated the $\mathrm{WNT} / \beta$-catenin signaling to lung adenocarcinoma progression. Thus, restoration of miR-33b expression could be used as a novel strategy for treatment of lung cancer.

\section{Acknowledgements}

The present study was supported in part by grants from the Central South University Innovation Foundation For Postgraduates (\#2015zzts114), the National Key Scientific and Technology Support Program-Collaborative Innovation of Clinical Research for Chronic Obstructive Pulmonary Disease and Lung Cancer (\#2013BAI09B09) and The National Natural Science Foundation of China for Young Scholars (\#81302311).

\section{References}

1. Travis WD, Travis LB and Devesa SS: Lung cancer. Cancer 75 (Suppl): 191-202, 1995.

2. Subramanian J and Govindan R: Lung cancer in never smokers: A review. J Clin Oncol 25: 561-570, 2007.

3. Kenfield SA, Wei EK, Stampfer MJ, Rosner BA and Colditz GA: Comparison of aspects of smoking among the four histological types of lung cancer. Tob Control 17: 198-204, 2008.

4. Gupta GP and Massagué J: Cancer metastasis: Building a framework. Cell 127: 679-695, 2006.

5. Finigan JH and Kern JA: Lung cancer screening: Past, present and future. Clin Chest Med 34: 365-371, 2013.

6. Leng S, Bernauer AM, Zhai R, Tellez CS, Su L, Burki EA, Picchi MA, Stidley CA, Crowell RE, Christiani DC, et al: Discovery of common SNPs in the miR-205/200 familyregulated epithelial to mesenchymal transition pathway and their association with risk for non-small cell lung cancer. Int J Mol Epidemiol Genet 2: 145-155, 2011.

7. Pirozzi G, Tirino V, Camerlingo R, Franco R, La Rocca A, Liguori E, Martucci N, Paino F, Normanno N and Rocco G: Epithelial to mesenchymal transition by TGF $\beta-1$ induction increases stemness characteristics in primary non small cell lung cancer cell line. PLoS One 6: e21548, 2011.
8. Acloque H, Adams MS, Fishwick K, Bronner-Fraser M and Nieto MA: Epithelial-mesenchymal transitions: The importance of changing cell state in development and disease. J Clin Invest 119: 1438-1449, 2009.

9. Maitah MY, Ali S, Ahmad A, Gadgeel S and Sarkar FH: Up-regulation of sonic hedgehog contributes to TGF- $\beta 1$-induced epithelial to mesenchymal transition in NSCLC cells. PLoS One 6: e16068, 2011.

10. Onder TT, Gupta PB, Mani SA, Yang J, Lander ES and Weinberg RA: Loss of E-cadherin promotes metastasis via multiple downstream transcriptional pathways. Cancer Res 68: 3645-3654, 2008.

11. Argast GM, Krueger JS, Thomson S, Sujka-Kwok I, Carey K, Silva S, O'Connor M, Mercado P, Mulford IJ, Young GD, et al: Inducible expression of TGF $\beta$, snail and Zeb1 recapitulates EMT in vitro and in vivo in a NSCLC model. Clin Exp Metastasis 28: 593-614, 2011.

12. Ren J, Chen Y, Song H, Chen L and Wang R: Inhibition of ZEB1 reverses EMT and chemoresistance in docetaxel-resistant human lung adenocarcinoma cell line. J Cell Biochem 114: 1395-1403, 2013.

13. Liu Y, Zhang N, Wang Y, Xu M, Liu N, Pang X, Cao J, Ma N, Pang H, Liu L, et al: Zinc finger E-box binding homeobox 1 promotes invasion and bone metastasis of small cell lung cancer in vitro and in vivo. Cancer Sci 103: 1420-1428, 2012.

14. Ghahhari NM and Babashah S: Interplay between microRNAs and $\mathrm{WNT} / \beta$-catenin signalling pathway regulates epithelialmesenchymal transition in cancer. Eur J Cancer 51: 1638-1649, 2015.

15. Clevers H: Wnt/beta-catenin signaling in development and disease. Cell 127: 469-480, 2006.

16. Choi YS, Shim YM, Kim SH, Son DS, Lee HS, Kim GY, Han J and Kim J: Prognostic significance of E-cadherin and betacatenin in resected stage I non-small cell lung cancer. Eur J Cardiothorac Surg 24: 441-449, 2003.

17. Woenckhaus M, Merk J, Stoehr R, Schaeper F, Gaumann A, Wiebe K, Hartmann A, Hofstaedter F and Dietmaier W: Prognostic value of FHIT, CTNNB1, and MUC1 expression in non-small cell lung cancer. Hum Pathol 39: 126-136, 2008.

18. Nakashima T, Liu D, Nakano J, Ishikawa S, Yokomise H, Ueno M, Kadota K and Huang CL: Wnt1 overexpression associated with tumor proliferation and a poor prognosis in non-small cell lung cancer patients. Oncol Rep 19: 203-209, 2008.

19. Nguyen DX, Chiang AC, Zhang XH, Kim JY, Kris MG, LadanyiM, Gerald WL and Massagué J: WNT/TCF signaling through LEF1 and HOXB9 mediates lung adenocarcinoma metastasis. Cell 138: 51-62, 2009.

20. Wang R, Wang ZX, Yang JS, Pan X, De W and Chen LB: MicroRNA-451 functions as a tumor suppressor in human non-small cell lung cancer by targeting ras-related protein 14 (RAB14). Oncogene 30: 2644-2658, 2011.

21. Garofalo M, Quintavalle C, Di Leva G, Zanca C, Romano G, Taccioli C, Liu CG, Croce CM and Condorelli G: MicroRNA signatures of TRAIL resistance in human non-small cell lung cancer. Oncogene 27: 3845-3855, 2008.

22. Puisségur MP, Mazure NM, Bertero T, Pradelli L, Grosso S, Robbe-Sermesant K, Maurin T, Lebrigand K, Cardinaud B, Hofman V, et al: miR-210 is overexpressed in late stages of lung cancer and mediates mitochondrial alterations associated with modulation of HIF-1 activity. Cell Death Differ 18: 465-478, 2011.

23. Bartel DP and Chen CZ: Micromanagers of gene expression: The potentially widespread influence of metazoan microRNAs. Nat Rev Genet 5: 396-400, 2004.

24. Bartel DP: MicroRNAs: Genomics, biogenesis, mechanism, and function. Cell 116: 281-297, 2004.

25. Kloosterman WP and Plasterk RH: The diverse functions of microRNAs in animal development and disease. Dev Cell 11: 441-450, 2006.

26. Gabriely G, Wurdinger T, Kesari S, Esau CC, Burchard J, Linsley PS and Krichevsky AM: MicroRNA 21 promotes glioma invasion by targeting matrix metalloproteinase regulators. Mol Cell Biol 28: 5369-5380, 2008.

27. Hwang HW and Mendell JT: MicroRNAs in cell proliferation, cell death, and tumorigenesis. Br J Cancer 94: 776-780, 2006.

28. Yang L, Li Q, Wang Q, Jiang Z and Zhang L: Silencing of miRNA-218 promotes migration and invasion of breast cancer via Slit2-Robo1 pathway. Biomed Pharmacother 66: 535-540, 2012. 
29. Cheng T, Hu C, Yang H, Cao L and An J: Transforming growth factor- $\beta$-induced miR-143 expression in regulation of non-small cell lung cancer cell viability and invasion capacity in vitro and in vivo. Int J Oncol 45: 1977-1988, 2014.

30. Luo Z, Dai Y, Zhang L, Jiang C, Li Z, Yang J, McCarthy JB, She $\mathrm{X}$, Zhang $\mathrm{W}$, Ma J, et al: miR-18a promotes malignant progression by impairing microRNA biogenesis in nasopharyngeal carcinoma. Carcinogenesis 34: 415-425, 2013.

31. Cong N, Du P, Zhang A, Shen F, Su J, Pu P, Wang T, Zjang J, Kang $C$ and Zhang Q: Downregulated microRNA-200a promotes EMT and tumor growth through the wnt $/ \beta$-catenin pathway by targeting the E-cadherin repressors ZEB1/ZEB2 in gastric adenocarcinoma. Oncol Rep 29: 1579-1587, 2013.

32. Licchesi JD, Westra WH, Hooker CM, Machida EO, Baylin SB and Herman JG: Epigenetic alteration of Wnt pathway antagonists in progressive glandular neoplasia of the lung. Carcinogenesis 29: 895-904, 2008.

33. Gao W, Xu J, Liu L, Shen H, Zeng H and Shu Y: A systematicanalysis of predicted miR-21 targets identifies a signature for lung cancer. Biomed Pharmacother 66: 21-28, 2012.

34. Jemal A, Bray F, Center MM, Ferlay J, Ward E and Forman D: Global cancer statistics. CA Cancer J Clin 61: 69-90, 2011.

35. Siegel R, Naishadham D and Jemal A: Cancer statistics, 2013. CA Cancer J Clin 63: 11-30, 2013.

36. Huang T, Chen Z and Fang L: Curcumin inhibits LPS-induced EMT through downregulation of NF- $\kappa \mathrm{B}-$ Snail signaling in breast cancer cells. Oncol Rep 29: 117-124, 2013.

37. Risé P, Ghezzi S, Carissimi R, Mastromauro F, Petroni A and Galli C: Delta5 desaturase mRNA levels are increased by simvastatin via SREBP-1 at early stages, not via PPARalpha, in THP-1 cells. Eur J Pharmacol 571: 97-105, 2007.

38. Cirera-Salinas D, Pauta M, Allen RM, Salerno AG, Ramírez CM, Chamorro-Jorganes A, Wanschel AC, Lasuncion MA, Morales-Ruiz M, Suarez Y, et al: Mir-33 regulates cell proliferation and cell cycle progression. Cell Cycle 11: 922-933, 2012.

39. Takwi AA, Li Y, Becker Buscaglia LE, Zhang J, Choudhury S, Park AK, Liu M, Young KH, Park WY, Martin RC, et al: A statin-regulated microRNA represses human c-Myc expression and function. EMBO Mol Med 4: 896-909, 2012.

40. Williams TM, Moolten D, Burlein J, Romano J, Bhaerman R, Godillot A, Mellon M, Rauscher FJ III and Kant JA: Identification of a zinc finger protein that inhibits IL-2 gene expression. Science 254: 1791-1794, 1991

41. Noble S and Goa KL: Aldesleukin (recombinant interleukin-2). BioDrugs 7: 394-422, 1997.

42. Bhatia S, Tykodi SS and Thompson JA: Treatment of metastatic melanoma: An overview. Oncology (Williston Park) 23: 488-496, 2009.

43. Shaker MA and Younes HM: Interleukin-2: Evaluation of routes of administration and current delivery systems in cancer therapy. J Pharm Sci 98: 2268-2298, 2009.
44. Liu W, Huang YJ, Liu C, Yang YY, Liu H, Cui JG, Cheng Y, Gao F, Cai JM and Li BL: Inhibition of TBK1 attenuates radiation-induced epithelial-mesenchymal transition of A549 human lung cancer cells via activation of GSK-3 $\beta$ and repression of ZEB1. Lab Invest 94: 362-370, 2014.

45. Spaderna S, Schmalhofer O, Hlubek F, Berx G, Eger A, Merkel S, Jung A, Kirchner T and Brabletz T: A transient, EMT-linked loss of basement membranes indicates metastasis and poor survival in colorectal cancer. Gastroenterology 131: 830-840, 2006.

46. Dohadwala M, Yang SC, Luo J, Sharma S, Batra RK, Huang M, Lin Y, Goodglick L, Krysan K, Fishbein MC, et al: Cyclooxygenase-2-dependent regulation of E-cadherin: Prostaglandin $\mathrm{E}(2)$ induces transcriptional repressors ZEB1 and snail in non-small cell lung cancer. Cancer Res 66: 5338-5345, 2006.

47. Sayan AE, Griffiths TR, Pal R, Browne GJ, Ruddick A, Yagci T, Edwards R, Mayer NJ, Qazi H, Goyal S, et al: SIP1 protein protects cells from DNA damage-induced apoptosis and has independent prognostic value in bladder cancer. Proc Natl Acad Sci USA 106: 14884-14889, 2009.

48. Wang Y, Wen M, Kwon Y, Xu Y, Liu Y, Zhang P, He X, Wang Q, Huang Y, Jen KY, et al: CUL4A induces epithelial-mesenchymal transition and promotes cancer metastasis by regulating ZEB1 expression. Cancer Res 74: 520-531, 2014.

49. Zhang G, He P, Gaedcke J, Ghadimi BM, Ried T, Yfantis HG, Lee DH, Hanna N, Alexander HR and Hussain SP: FOXL1, a novel candidate tumor suppressor, inhibits tumor aggressiveness and predicts outcome in human pancreatic cancer. Cancer Res 73: 5416-5425, 2013

50. Ohashi S, Natsuizaka M, Naganuma S, Kagawa S, Kimura S, Itoh H, Kalman RA, Nakagawa M, Darling DS, Basu D, et al: A NOTCH3-mediated squamous cell differentiation program limits expansion of EMT-competent cells that express the ZEB transcription factors. Cancer Res 71: 6836-6847, 2011.

51. Eger A, Aigner K, Sonderegger S, Dampier B, Oehler S, Schreiber M, Berx G, Cano A, Beug H and Foisner R: DeltaEF1 is a transcriptional repressor of E-cadherin and regulates epithelial plasticity in breast cancer cells. Oncogene 24: 2375-2385, 2005.

52. Xu X, Sun PL, Li JZ, Jheon S, Lee CT and Chung JH: Aberrant Wnt $1 / \beta$-catenin expression is an independent poor prognostic marker of non-small cell lung cancer after surgery. J Thorac Oncol 6: 716-724, 2011

53. He B, You L, Uematsu K, Xu Z, Lee AY, Matsangou M, McCormick $\mathrm{F}$ and Jablons DM: A monoclonal antibody against Wnt-1 induces apoptosis in human cancer cells. Neoplasia 6: $7-14,2004$.

54. Brabletz T, Jung A, Reu S, Porzner M, Hlubek F, KunzSchughart LA, Knuechel R and Kirchner T: Variable beta-catenin expression in colorectal cancers indicates tumor progression driven by the tumor environment. Proc Natl Acad Sci USA 98: 10356-10361, 2001. 